\title{
Effect of sowing time on growth and yield attributes of three mustard cultivars grown in Tidal Floodplain of Bangladesh
}

\author{
M. A. R. Sharif ${ }^{1}$, M. Z. Haque ${ }^{1}$, M. H. K. Howlader ${ }^{2}$ and M. J. Hossain ${ }^{3^{*}}$ \\ ${ }_{1 \& 2}$ Department of Crop Botany, Patuakhali Science \& Technology University and ${ }^{3}$ International Rice Research \\ Institute, Bangladesh, E-mail: m.j.hossain@irri.org
}

\begin{abstract}
The experiment was conducted at the field laboratory of the Patuakhali Science and Technology University, Patuakhali, Bangladesh during the period from November, 2011 to March 2012 under the tidal Floodplain region to find out optimum sowing time for the selected three cultivars (BARI Sharisha-15, BINA Sharisha-5 and BARI Sharisha-9). There were four sowing dates viz. 30 November, 15 December, 30 December and 15 January. Significant variations due to different sowing dates were observed in plant height, total dry matter, leaf area index, number of siliqua plant ${ }^{-1}$, seeds silique ${ }^{-1}, 1000$-grain weight, grain yield and HI. Results showed that the highest grain

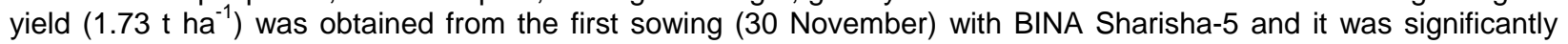
different from the yields of all other combination.
\end{abstract}

Keyword: Floodplain, Growth attributes, Mustard, Sowing time, Yield

\section{Introduction}

Oilseed rape (Brassica napusL.) has become one of the most important oil crops (Miri, 2007) and at present, is the third largest source of vegetable oil all over the world (Starner et al., 1999). In Bangladesh context, mustard (Brassica spp.) is a popular edible oil in rural area and is considered important for improving the taste of a number of food items (Aziz et al., 2011a). Bangladesh is principally an agricultural country and produces a good number of oilseed crops like mustard, sesame, groundnut, linseed, safflower, sunflower, soybean, castor etc. The first three of these are considered as the major oil seed crops. Mustard and rapeseed are quietly significant in Bangladesh economy. It is an important and the top ranking oil seed crop in Bangladesh. Rapeseed (Brassica campestris L.) commonly known as mustard oil seed crop in Bangladesh, is a cool season crop. It is also a thermo sensitive as well as photosensitive crop (Ghosh and Chatterjee, 1988). It also serves as an important raw material for industrial use such as in soap, paints, varnishes, hair oils, lubricants, textile auxiliaries, pharmaceuticals, etc. Its oil not only plays a great role as fat substitute in our daily diet but also nourish the economy of the nation. It is widely used as a cooking ingredient, condiment and for its medicinal value. Moreover, mustard oil cake is utilized as cattle feed and small quantities are also used as manure. It accounts about $72 \%$ of total oilseed production in the country. The area under rapeseed and mustard is 0.30 million hectares which is about $80 \%$ of the total oilseed area (Anonymous, 2003). Last ten years have witnessed gradual decline in an area of 104 thousand hectare and production 68 thousand tons of mustard and rapeseed (Anonymous, 2006). Though the production of edible oil is being decreased, whereas, the demand is increasing day by day with the increasing population. The present domestic edible oilseed production is 267 thousand tons which meets only one third of national demand (Anonymous, 2006).Finally 2010, the total rapeseed harvested area 598000 ha and yield $371 \mathrm{~kg}^{2}$ acre $^{-1}$ and the production quantity 222000 tons in Bangladesh (BBS, 2011). Cultivation of low yielder local varieties late sowing are the major causes for poor yield of mustard in the country (Alam and Rahman, 2006). High yield potential of a variety is the prerequisite for increasing the production of a crop. In the recent years, Bangladesh Agricultural Research Institute (BARI) \& BINA has developed a number of high yielding varieties of mustard with yield potential up to $2.5 \mathrm{t} \mathrm{ha}^{-1}$. The present national average yield of mustard is only $0.79 \mathrm{t} \mathrm{ha}^{-1}$ (Anonymous, 2006). Genotypes play an important role in crop production and the potential yield of a genotype within the genetic limit is determined by its environment (Iraddi, 2008). The release of high yielding varieties has contributed a great deal towards the improvement of Mustard yields. The yield potential of these high yielding varieties can be further exploited through better agronomic practices involving many physiological changes. Delayed planting, inappropriate weather conditions in tidal floodplain region during the flowering period, fertilization and pod formation can cause a decrease in duration of maturity period, affect the number of pods per plant, affect the number and weight of grains and finally can lead to decrease in grain yield (Rahnama and Bakhshandeh, 2005). The present study was undertaken to identify suitable genotype with standard sowing time for increase mustard production and expansion of cultivation area in tidal floodplain region of Bangladesh. 


\section{Materials and Methods}

A field experiment was conducted at the Field Laboratory of the Patuakhali Science and Technology University, Patuakhali, Bangladesh during the period from November, 2011 to March 2012 under the tidal Floodplain region. Geographically, the research farm is located at $22^{\circ} 37^{\prime} \mathrm{N}$ latitude and $89^{\circ} 10^{\prime} \mathrm{E}$ longitudes. The area is covered Gangetic Tidal Floodplains and falls under Agro-ecological Zone "AEZ13".Soil characteristics of the southern part of the research farm are clay loams. However, the soil of the experimental field was silty caly loam having $\mathrm{pH}$ value of 7.00.Generally, Patuakhali region falls under the sub-tropical climate, which is characterized by high temperature and humidity, heavy rainfall with occasional gusty winds in the month of April to September (Kharif Season) and scanty rainfall during the rest period of the year (Biswas, 1987). The Rabi season (October to March) is characterized by comparatively low temperature and plenty of sunshine from November to February (SRDI, 1991). The experiment was consisted with two factors where three Mustard genotypes viz., BARI Sharisha-15 $\left(\mathrm{V}_{1}\right)$, BINA Sharisha-5 $\left(V_{2}\right)$ and BARI Sharisha-9 $\left(V_{3}\right)$ was used as a factor $A$ and four sowing time viz. 30 November $\left(T_{1}\right), 15$ December $\left(T_{2}\right), 30$ December $\left(T_{3}\right)$ and 15 January $\left(T_{4}\right)$ were used as a factor $B$. The experimental design was Randomized Complete Block Design (RCBD) with three replications. The size of each unit plot was $2.0 \mathrm{~m} \times 2.0 \mathrm{~m}$ where line to line and plant to plant distances were 10 and $6 \mathrm{~cm}$, respectively, in each plot. The applied fertilizers were mixed properly with the soil in the plot using a spade. Urea (220 kg/ha), TSP (180 kg/ha), MOP (50 kg/ha) and Gypsum (120 kg/ha) (Fertilizer Recommended Guide, BARC, 1997) were used. Data were collected on plant height, Total dry matter, leaf area index, number of siliqua plant ${ }^{-1}$, number of seed silique ${ }^{-1}, 1000$ grains weight, and grain yield $\mathrm{t} \mathrm{ha}{ }^{-1}$. The collected data were analyzed using computer package MSTAT and mean differences were adjudged by using Duncan's Multiple Range Test.

Table 1. Chemical and physical characteristics of soil at experimental sites

\begin{tabular}{|c|c|c|c|c|c|c|c|}
\hline Sample & $\begin{array}{l}\text { Phosphorus } \\
\text { (ppm) }\end{array}$ & 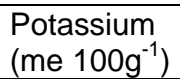 & $\begin{array}{l}\text { Sulphur } \\
\text { (ppm) }\end{array}$ & $\mathrm{pH}$ & $\begin{array}{l}\text { Salinity (ds } \\
\mathrm{m}^{-1} \text { ) }\end{array}$ & $\begin{array}{l}\text { Organic } \\
\text { Matter }\end{array}$ & Total N (\%) \\
\hline Soil & 16.1 & 0.30 & 10.8 & 7.0 & 0.65 & 1.53 & 0.077 \\
\hline Water & - & - & - & 7.3 & 0.56 & - & - \\
\hline
\end{tabular}

\section{Results and Discussion}

Plant height: The effect of different cultivars with sowing time on mustard plant height was measured from 30 DAS until harvest at 15 days interval and the results presented in Table 2. The plant height was significantly higher in all cultivars with 30 November sowing at all the stages. The highest plant height was $112.6 \mathrm{~cm}$ found in BINA Sharisha-5 with 30 November sowing and the lowest $(93.8 \mathrm{~cm})$ in BARI Sharisha-9 with 15 January sowing at final harvest. Plant height is one of the most important growth contributing characters for any corps which would be related on several factors like genetic makeup, nutrient availability, environmental or climatic condition, soil characteristics, regional adaptability etc. Similar findings were also obtained by Umeh et al. (2011). Mahmud Abadi et al. (2008) studied the various types of autumnal canola in the region of Bojnoord. They reported that delay (from September 30th to October 26th) in planting the most of its types, leads to a decrease in the plant height and biological performance. These results revealed that the high yielding mustard genotype noticed the higher growth in early sowing.

Total dry matter (TDM): The cumulative accumulation of total dry matter (TDM) of different parts at various stages of growth is presented in Fig. 1 and Table 3. The initial smaller accumulation of TDM linearly increased up to about maturity in most all the treatments. All the cultivars increased the TDM accumulation with 30 November sowing in all the growth stages but maximum DM accumulation was (21.63g plant ${ }^{-} 1$ )found in BARI Sharisha-9 plants treated with 30 November sowing. Hokmalipour et al. (2011) observed the similar results with the present study where the total dry matter was affected significantly by canola cultivars and sowing date. The highest quantities of total dry matter were obtained in the first sowing date. So, we can suggest using the first sowing date. Total dry matter was significantly influenced by the combined effect between mustard genotypes and sowing time at different days after sowing (Table 3). 
Sharif et al.

Table 2. Effect of sowing time on plant height at different days after sowing (DAS)in 3 mustard cvs

\begin{tabular}{|c|c|c|c|c|c|c|}
\hline \multirow{2}{*}{ Genotypes } & \multirow{2}{*}{$\begin{array}{l}\text { Sowing } \\
\text { time }\end{array}$} & \multicolumn{5}{|c|}{ Plant height $(\mathrm{cm})$ at different DAS } \\
\hline & & 30 & 45 & 60 & 75 & Harvest \\
\hline \multirow[t]{4}{*}{ BARI Sharisha-15 } & $30 \mathrm{Nov}$ & $36.27 \mathrm{e}$ & $59.26 \mathrm{e}$ & $76.28 \mathrm{e}$ & $94.25 \mathrm{e}$ & $99.29 \mathrm{e}$ \\
\hline & $15 \mathrm{Dec}$ & 36.00 ef & $59.00 \mathrm{e}$ & $75.98 \mathrm{e}$ & $94.01 \mathrm{e}$ & 99.00 ef \\
\hline & $30 \mathrm{Dec}$ & $35.11 \mathrm{fg}$ & 58.11 ef & 75.44 ef & $93.12 \mathrm{f}$ & $98.12 \mathrm{fg}$ \\
\hline & 15 Jan & $34.71 \mathrm{~g}$ & $57.71 \mathrm{f}$ & $74.72 \mathrm{f}$ & $92.72 \mathrm{f}$ & $97.73 \mathrm{~g}$ \\
\hline \multirow[t]{4}{*}{ BINA Sharisha-5 } & $30 \mathrm{Nov}$ & $42.58 \mathrm{a}$ & $67.58 \mathrm{a}$ & $89.58 \mathrm{a}$ & $107.6 \mathrm{a}$ & $112.6 \mathrm{a}$ \\
\hline & $15 \mathrm{Dec}$ & $41.27 \mathrm{~b}$ & $66.27 \mathrm{~b}$ & $88.27 b$ & $106.3 \mathrm{~b}$ & $111.3 \mathrm{~b}$ \\
\hline & $30 \mathrm{Dec}$ & $39.99 \mathrm{c}$ & $64.66 \mathrm{c}$ & $86.67 \mathrm{C}$ & $104.7 \mathrm{C}$ & $109.7 \mathrm{C}$ \\
\hline & 15 Jan & $38.43 \mathrm{~d}$ & $63.44 d$ & $85.43 \mathrm{~d}$ & $103.4 \mathrm{~d}$ & $108.4 d$ \\
\hline \multirow[t]{4}{*}{ BARI Sharisha-9 } & $30 \mathrm{Nov}$ & $34.42 \mathrm{~g}$ & $57.42 \mathrm{f}$ & $74.43 \mathrm{f}$ & $92.43 \mathrm{f}$ & $97.76 \mathrm{~g}$ \\
\hline & $15 \mathrm{Dec}$ & $32.44 \mathrm{~h}$ & $55.45 \mathrm{~g}$ & $72.46 \mathrm{~g}$ & $90.44 \mathrm{~g}$ & $95.46 \mathrm{~h}$ \\
\hline & $30 \mathrm{Dec}$ & $31.54 \mathrm{i}$ & $54.54 \mathrm{gh}$ & $71.54 \mathrm{gh}$ & $89.56 \mathrm{~h}$ & $94.54 \mathrm{hi}$ \\
\hline & 15 Jan & $30.77 \mathrm{i}$ & $53.77 \mathrm{~h}$ & $70.77 \mathrm{~h}$ & $88.78 \mathrm{~h}$ & $93.78 \mathrm{i}$ \\
\hline \multicolumn{2}{|c|}{$\mathrm{LSD}_{0.05}$} & 0.9008 & 1.100 & 1.121 & 0.8295 & 1.033 \\
\hline \multicolumn{2}{|c|}{ Level of sig. } & 0.01 & 0.05 & 0.05 & 0.01 & 0.01 \\
\hline \multicolumn{2}{|c|}{ CV\% } & 1.47 & 1.09 & 0.84 & 0.51 & 0.60 \\
\hline
\end{tabular}
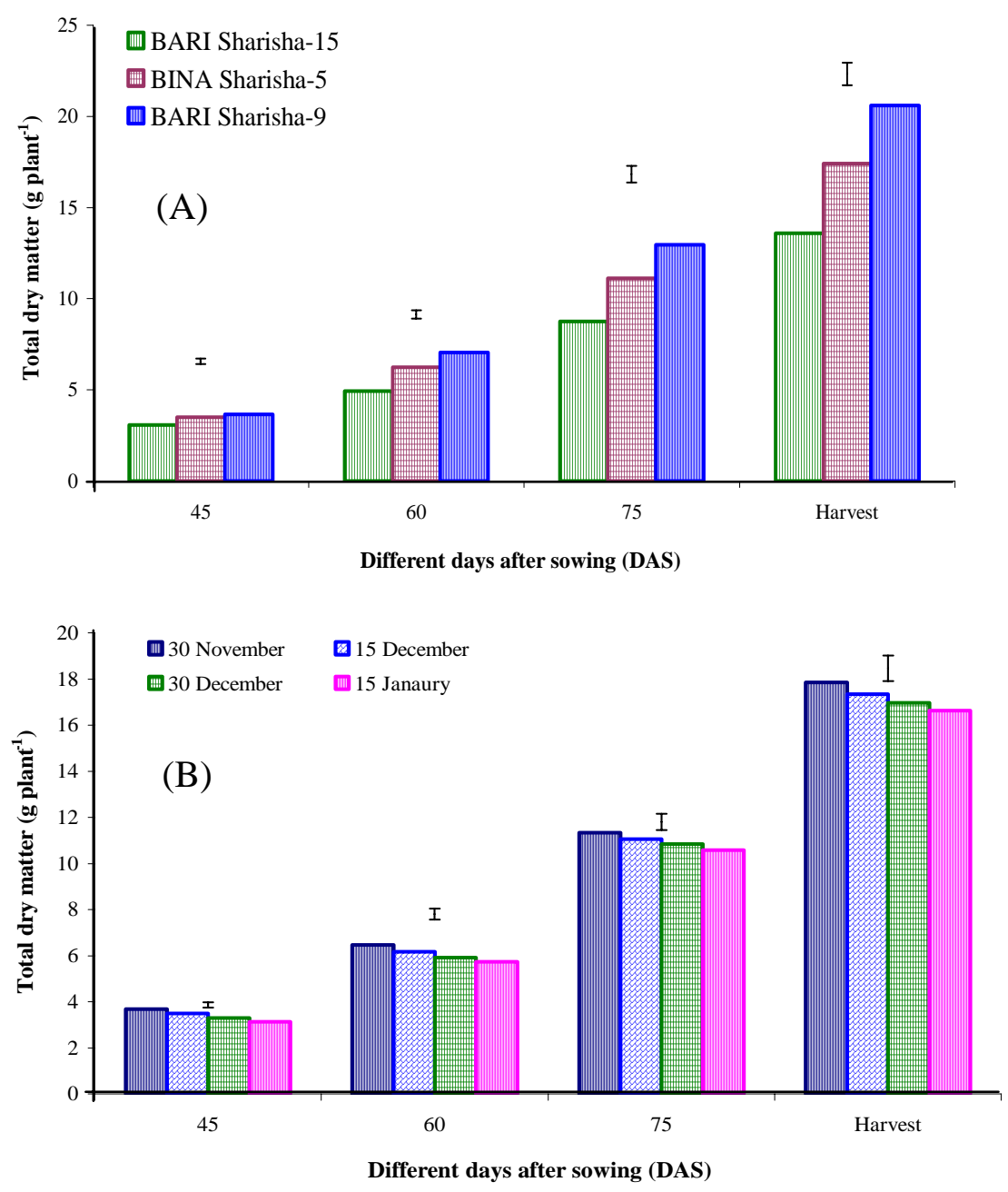

Fig.1. Effect of mustard genotypes (A) and sowing time (B) on total dry matter at different days after sowing. Vertical bars represent LSD at $5 \%$ level of probability 
Table 3. Effect of sowing time on total dry matter (TDM) at different days after sowing in $\mathbf{3}$ mustard cultivars

\begin{tabular}{|c|c|c|c|c|c|}
\hline \multirow{2}{*}{ Genotypes } & \multirow{2}{*}{ Sowing time } & \multicolumn{4}{|c|}{ TDM $\left(\mathrm{g}\right.$ plant $^{-1}$ ) at different DAS } \\
\hline & & 45 & 60 & 75 & Harvest \\
\hline \multirow[t]{4}{*}{ BARI Sharisha-15 } & $30 \mathrm{Nov}$ & $3.310 \mathrm{de}$ & $5.167 \mathrm{f}$ & $9.120 \mathrm{e}$ & $14.16 \mathrm{~d}$ \\
\hline & $15 \mathrm{Dec}$ & 3.143 ef & $5.003 \mathrm{fg}$ & 8.860 ef & $13.71 \mathrm{~d}$ \\
\hline & $30 \mathrm{Dec}$ & $2.973 \mathrm{fg}$ & $4.850 \mathrm{fg}$ & $8.647 \mathrm{fg}$ & $13.47 \mathrm{~d}$ \\
\hline & 15 Jan & $2.800 \mathrm{~g}$ & $4.677 \mathrm{~g}$ & $8.377 \mathrm{~g}$ & $13.00 \mathrm{~d}$ \\
\hline \multirow[t]{4}{*}{ BINA Sharisha-5 } & $30 \mathrm{Nov}$ & $3.710 \mathrm{bc}$ & $6.583 \mathrm{~cd}$ & $11.36 \mathrm{~d}$ & $17.76 \mathrm{c}$ \\
\hline & $15 \mathrm{Dec}$ & $3.517 \mathrm{~cd}$ & $6.327 \mathrm{de}$ & $11.18 \mathrm{~d}$ & $17.31 \mathrm{c}$ \\
\hline & $30 \mathrm{Dec}$ & $3.430 \mathrm{cde}$ & $6.083 \mathrm{e}$ & $11.05 \mathrm{~d}$ & $17.11 \mathrm{c}$ \\
\hline & 15 Jan & 3.310 de & $5.983 \mathrm{e}$ & $10.93 d$ & $17.48 \mathrm{c}$ \\
\hline \multirow[t]{4}{*}{ BARI Sharisha-9 } & $30 \mathrm{Nov}$ & $4.057 \mathrm{a}$ & $7.640 \mathrm{a}$ & $13.51 \mathrm{a}$ & $21.63 \mathrm{a}$ \\
\hline & $15 \mathrm{Dec}$ & $3.803 \mathrm{ab}$ & $7.200 \mathrm{~b}$ & $13.13 \mathrm{ab}$ & $20.99 \mathrm{a}$ \\
\hline & $30 \mathrm{Dec}$ & $3.473 \mathrm{~cd}$ & $6.800 \mathrm{bc}$ & $12.80 \mathrm{bc}$ & $20.29 a b$ \\
\hline & 15 Jan & $3.300 \mathrm{de}$ & $6.570 \mathrm{~cd}$ & $12.41 \mathrm{c}$ & $19.44 \mathrm{~b}$ \\
\hline $\mathrm{LSD}_{0.05}$ & & 0.2677 & 0.4113 & 0.4148 & 1.280 \\
\hline Level of sig. & & 0.01 & 0.01 & 0.01 & 0.01 \\
\hline CV\% & & 1.16 & 2.16 & 2.19 & 1.81 \\
\hline
\end{tabular}

Leaf area index (LAI):The variation of leaf area index (LAI) as influenced by cultivars and sowing time has been evaluated from 45 DAS until maturity and the results are presented in Fig. 2 (A \&B). The data on LAl showed that it was gradually increased up to 75 DAS and after attaining the maxima, the LAls declined up to maturity. Among the cultivars, the LAI had maximum (1.2) in BINA Sharisha-5 at 75 DAS which significantly differed with other cultivars and the lowest LAI (0.91) was found in BARI Sharisha-9 at same stage. This variation was indicated that the different variety were different effect on LAI in case of the variation in genetic makeup and their regional adaptability in southern part of Patuakhali. Ahmed and Jabereldar (2010) were studied on growth and yield of three cultivars of cowpea (Buff, Haydoob and EienElgazal) were the local cultivar (buff) had higher LAI in case of the genetic variability. LAl data was also showed significant different among the sowing times at different days after sowing .Maximum LAI was observed (1.1) in 30 November sowing at 75 DAS which was statistically similar with 15 December sowing. These results indicated that early sowing produces the higher LAl at every stages in case of the similar results was attain for LA. Sharma, et al. (2006) reported that the leaf area index was maximum in the crop sown on 22nd and 29th Oct. compared to early and late sowing of 6th Oct. and 12th Nov. respectively. Panda et al. (2004) also reported that delayed sowing beyond 16th October reduced the leaf area index leaf (LAI) and area duration (LAD).
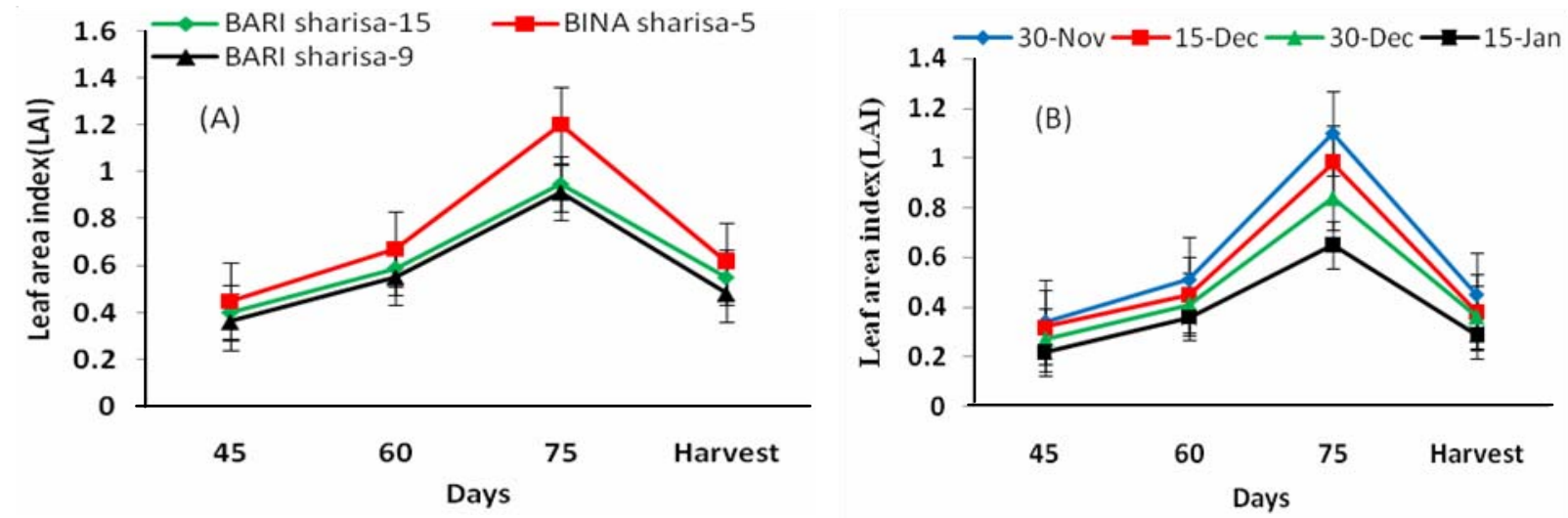

Fig. 2. Effect of mustard cultivars (A) and sowing time (B) on leaf area index at different days after sowing. Vertical bars represent LSD at $5 \%$ level of probability 
Number of siliqua plant ${ }^{-1}$ : The maximum number of siliqua plant ${ }^{-1}$ (194.70) was found from the treatment combination of the variety BINA Sharisha-5 and early sowing of 30 November and the minimum was117.0 in BARI Sharisha-9 with delay sowing at 15 January (Table 4). Similar findings were also observed by Umeh et al. (2011). Aziz et al. (2011a) also reported the early planting recorded the higher number of siliqua (253.9).

Number of grainssilique ${ }^{-1}$ : A significant variation was also obtained with the combined effect between mustard varieties and their sowing time (Table 4). The maximum no. of seed siliqua ${ }^{-1}(22.00)$ was found from the variety BINA Sharisha-5 in 30 November sowing which was significantly differed with other treatment combinations. And the minimum no. of seed siliqua ${ }^{-1}$ was 13.00 in delay sowing of BARI Sharisha-9. These results indicated that the high yield recommended variety BINA Sharisha-5 produced the maximum seed in early sowing in case of the favorable climatic condition was attained at this period. Umehet al. (2011) found variation among the genotypes where number of seed in TGX 1740 produced the better results compare to Max-TGX 1440. Aziz et al. (2011a) found that early sowing mustard on 15 November produced the maximum seeds silique ${ }^{-1}(13.40)$.

Table 4. Effect of genotype and sowing time on yield characters of mustard at harvest

\begin{tabular}{|c|c|c|c|c|c|c|}
\hline Genotypes & Sowing time & $\begin{array}{c}\text { Number of } \\
\text { siliqua plant }^{-1}\end{array}$ & $\begin{array}{c}\text { Number of } \\
\text { seed siliqua }^{-1}\end{array}$ & $\begin{array}{l}\text { 1000-seed } \\
\text { weight }(\mathrm{g})\end{array}$ & $\begin{array}{c}\text { Grain yield (t } \\
\mathrm{ha}^{-1} \text { ) }\end{array}$ & $\mathrm{HI}(\%)$ \\
\hline BARI & $30 \mathrm{Nov}$ & $166.7 \mathrm{C}$ & $19.33 \mathrm{~b}$ & $2.89 \mathrm{~cd}$ & $1.56 \mathrm{~d}$ & 32.43 \\
\hline \multirow[t]{3}{*}{ Sharisha-15 } & $15 \mathrm{Dec}$ & $155.0 \mathrm{e}$ & $18.00 \mathrm{bc}$ & $2.75 \mathrm{e}$ & $1.48 \mathrm{e}$ & 31.87 \\
\hline & $30 \mathrm{Dec}$ & $142.0 \mathrm{f}$ & 15.33 def & $2.59 \mathrm{f}$ & 1.42 ef & 31.37 \\
\hline & 15 Jan & $138.0 \mathrm{~g}$ & $14.67 \mathrm{efg}$ & $2.34 \mathrm{~g}$ & $1.33 \mathrm{~g}$ & 31.34 \\
\hline BINA & $30 \mathrm{Nov}$ & $194.7 \mathrm{a}$ & $22.00 \mathrm{a}$ & $3.29 \mathrm{a}$ & $1.94 \mathrm{a}$ & 32.67 \\
\hline \multirow[t]{3}{*}{ Sharisha-5 } & $15 \mathrm{Dec}$ & $180.7 b$ & $19.33 \mathrm{~b}$ & $3.14 \mathrm{~b}$ & $1.77 \mathrm{~b}$ & 32.27 \\
\hline & $30 \mathrm{Dec}$ & $166.0 \mathrm{c}$ & $16.67 \mathrm{~cd}$ & $2.95 \mathrm{c}$ & $1.66 \mathrm{c}$ & 31.97 \\
\hline & $15 \mathrm{Jan}$ & $161.3 \mathrm{~d}$ & $15.67 \mathrm{de}$ & $2.78 \mathrm{de}$ & $1.59 \mathrm{~cd}$ & 31.67 \\
\hline BARI & $30 \mathrm{Nov}$ & $132.0 \mathrm{~h}$ & $16.67 \mathrm{~cd}$ & $2.49 \mathrm{f}$ & $1.36 \mathrm{fg}$ & 31.30 \\
\hline \multirow[t]{3}{*}{ Sharisha-9 } & $15 \mathrm{Dec}$ & $126.7 \mathrm{i}$ & $15.67 \mathrm{de}$ & $2.25 \mathrm{~g}$ & $1.22 \mathrm{~h}$ & 30.21 \\
\hline & 30 Dec & $120.0 \mathrm{j}$ & $13.67 \mathrm{fg}$ & $2.09 \mathrm{~h}$ & $1.16 \mathrm{~h}$ & 29.89 \\
\hline & 15 Jan & $117.0 \mathrm{k}$ & $13.00 \mathrm{q}$ & $1.99 \mathrm{~h}$ & $1.08 \mathrm{i}$ & 29.63 \\
\hline $\mathrm{LSD}_{005}$ & & 3.09 & 0.092 & 0.12 & 0.12 & 0.26 \\
\hline Level of siq. & & 0.01 & 0.01 & 0.05 & 0.05 & ns \\
\hline CV\% & & 1.22 & 3.34 & 1.50 & 1.50 & 1.75 \\
\hline
\end{tabular}

1000-grains weight: The interaction effect of cultivars and sowing times on thousand grain weight showed significant variation at $5 \%$ level of probability are presented in Table 4 . The highest weight of 1000 seeds (3.29 g) was recorded from the variety BINA Sharisha-5 in early sowing of 30 November which was significantly differed with other treatment combinations. In contrast, the lowest weight of 1000-seeds (1.99 g) was found from the variety BARI Sharisha-9 in delay sowing of 15 January which was statistically similar $(2.093 \mathrm{~g})$ with the same variety in 30 December sowing. Similar results were also observed by Ekram and Mahfouz (2010). early sowing mustard on 15 November produced the maximum 1000 grains weight (3.87 g) and reported by Aziz et al. (2011a).

Grain yield: A significant variation was observed among the combined effect of the three mustard cultivars and their sowing time in respect of grain yield (Table 4). The highest grain yield $\left(1.94 \mathrm{t} \mathrm{ha}^{-1}\right)$ was recorded from the treatment combination of the variety BINA Sharisha-5 and 30 November sowing and the lowest $\left(1.08 \mathrm{t} \mathrm{ha}^{-1}\right)$ in delay sowing at 15 January with BARI Sharisha-9 (Table 4). These results revealed that all the treatment combinations were showed significant variations regarding to grain yield. Besides, grain yield significantly decreased in increasing sowing time among the varieties. Wang et al. (2012) were studied on the impact of sowing date and historical climate where the results revealed that canola yield declined linearly with late sowing time, mainly due to shortened vegetative growth stages, and varied significantly due to inter-annual climate variability. Grain yield also had higher in first or early planting reported by Aziz et al. (2011a). As a result, it was found that sowing time is an important factor for seed yield and quality in rapeseed.

Harvest index: No significant variation was observed between cultivars and sowing time (Table 4). Maximum $\mathrm{HI}$ was found in BINA sharisha-5 with 30 November combination and the minimum in BARI Sharisha-9 with 15 January seed sowing in southern region in Bangladesh. 
Correlation: Total dry matter was positive relation with plant height, no. of branch/plant, LAI, thousand seed wt., grain yield and $\mathrm{HI}$ are presented in Table 5.

Table 5. Correlation of total dry matter with morpho-physiological and yield component parameters

\begin{tabular}{|c|c|c|c|c|c|c|}
\hline & TDM & Plant height & LAl & Thousand seed wt. & Grain Yield & $\mathrm{HI}$ \\
\hline TDM & 1 & $0.111 N S$ & $0.24 \mathrm{NS}$ & 0.33 NS & $0.30 \mathrm{NS}$ & $0.52 \mathrm{NS}$ \\
\hline Plant height & & 1 & $0.88^{\star \star}$ & $0.89^{\star \star}$ & $0.93^{\star *}$ & $0.76^{\star \star}$ \\
\hline LAI & & & 1 & $0.98^{\star \star}$ & $0.97^{\star \star}$ & $0.91^{\star \star}$ \\
\hline Thousand seed wt. & & & & 1 & $0.99^{\star *}$ & $0.95^{\star *}$ \\
\hline Grain Yield & & & & & 1 & $0.93^{\star \star}$ \\
\hline $\mathrm{HI}$ & & & & & & 1 \\
\hline
\end{tabular}

\section{Conclusion}

Above the investigation it could be concluded that the maximum yield potential explored in variety BINA Sharisha-5 with30 November sowing recorded the better morph-physiological growth to compare others combination under the southern part of Patuakhali district in Bangladesh.

\section{References}

Alam, M.M. and Rahman, M.M. 2006. Effect of row spacing on seed yield of five varieties of Rapeseed. Bangladesh J. Crop Sci.,17(1): 163-168.

Anonymous. 2003. Tel Fasaler Utpadan Prajukti (In Bangla), Oil Seed Res. Centre, Bangladesh Agril. Res. Inst., Joydebpur, Gazipur. 1-102.

Anonymous. 2006. Bangladesh Bureau of Statistics. Monthly Statistical Bulletin of Bangladesh. January, Statistics Div., Ministry of Planning, Govt. People's Repub. Bangladesh. 54.

Aziz, M.A., Rahman, A.K.M.M., Chakma, R., Ahmed, M. and Ahsan, A.F.M.S. 2011a. Performance of mustard varieties in the hilly areas of Bangladesh. J. Expt. Biosci., 2(2):7-10

BARC (Bangladesh Agricultural Res. Council). 1997. Fertilizer Recommendation Guide. Soils Pub. No. 41. 1997. Farmgate, Dhaka. pp. 25-184.

BBS (Bangladesh Bureau of Statistics). 2011.Bangladesh Bureau of Statistics Division, Govt. of the People's Republic of Bangladesh. pp.38.

Biswas, P.K. 1987. A study on the relative merits of mixed cropping under two levels of irrigations. MS Thesis, Dept. Agron. Bangladesh Agric. Univ. Mymensingh. p. 38-40.

Ghosh, R.K. and Chatterjee, B.N. 1988.Effect of dates of sowing on oil content and fatty acid profiles of Indian mustard. Indian J. Oilseed Res., 5(2):144-149.

Gomez, K.A. and Gomez, A.A. 1984. Statistical Procedures for Agricultural Research. A Wiley Int. Sci. Publ. John Wiley and Sons. New York, Brisbane, Singapore. pp. 139-240.

Hokmalipour, S., Tobe, A., Jafarzadeh, B. and Darbandi, M.H. 2011. Effect of sowing date on physiological growth induces in Canola (Brassica napusL.) cultivars in Meshkin region. Applied Sci. J., 14(4): 514-522.

Iraddi, V.S. 2008. Response of mustard [Brassica juncea (L.)] varieties to date of sowing and row spacing in northern transition zone of karnataka. MS in Agronomy, Department of Agronomy, College of Agriculture, Dharwad University of Agricultural Sciences, Dharwad-580005. pp. 1-81.

Mahmud Abadi, A., Azizi, M. and Gazanchian, A. 2008.The effect of planting date on the agriculture of different types of winter canola in the region of Bojnoored. The summary of the articles of the Tenth Congress of Agriculture and Plant Breeding Science of Iran, 1387 August 19th-20th, Karaj.

Miri, H.R. 2007. Morphophysiological basis of variation in rapeseed (Brassica napusL.)Yield. Inter. J. Agric. Biol., 9: $701-706$.

Panda, B.B., Bandyopadhyay, S.K. and Shivay, Y.S. 2004.Effect of irrigation level, sowing dates and varieties on yield attributes, yield, consumptive water use and water-use efficiency of Indian mustard (Brassica juncea). Indian J. Agric. Sci., 74(6): 339-342.

Rahnama, A.A. and Bakhshandeh, A. 2005. Effect of sowing dates and direct seeding and transplanting methods on agronomic characteristics and grain yield of Canola under Ahvaz conditions. Iranian J. Crop Sci., 7(4): 324-336.

Sharma, S.K., Mendhe, S.N., Kolte, H.S., Rajput, G.R. and Yenpreddiwar, M.D. 2006. Effect of sowing and irrigation management on growth and yield of mustard (Brassica juncea).J. Soils and Crops. 16(2): 455-459.

SRDI. 1991. Land and Soil Resource Utilization Guide: Mymensingh Sadar Thana, Mymensingh. (In Bangali). SRDI, Ministry of Agricultural, Dhaka, Bangladesh. P. 3.

Starner, D.E., Hamama, A. and Bhardwaj, H.L. 1999. Canola oil yield and quality as affected by production practices in Virginia. J. Janick (Ed), progress in new crops. ASHS Press. Alexandria Va., USA. pp: 254-256.

Umeh, M.O., Edeoga, H.O. and Omosun, G. 2011. Nitrogen fertilizer type and rate effects on growth and yield response of soybean varieties. Continental J. Agron., 5(2): 1-8.

Wang, S., Wang, E., Wang, F. and Tang, L. 2012. Phenological development and grain yield of canola as affected by sowing date and climate variation in the Yangtze River Basin of China. Crop and Pasture Sci., 63(5): 478-488. 